\title{
Nagłe zatrzymanie krążenia u 5-letniego chłopca z padaczką
}

\author{
Sudden cardiac arrest in 5-year-old boy with epilepsy
}

\author{
Agnieszka Stańko, Joanna Kwiatkowska, Mariusz Zipser \\ Katedra i Klinika Kardiologii Dziecięcej i Wad Wrodzonych Serca Gdańskiego Uniwersytetu Medycznego
}

\section{Streszczenie}

Zespół wydłużonego odstępu QT jest jednostką o zwiększonym ryzyku nagłego zgonu sercowego, często stanowiącą duże wyzwanie diagnostyczne. Przedstawiono przypadek 5-letniego chłopca z rozpoznaną padaczką, u którego doszło do nagłego zatrzymania krążenia w trakcie kolejnego napadu drgawkowego. Po skutecznej reanimacji dziecko przewieziono na oddział intensywnej terapii, gdzie na podstawie zapisów EKG z kardiomonitora rozpoznano nawracające częstoskurcze komorowe monomorficzne i typu torsade de pointes, a po powrocie rytmu zatokowego - wydłużenie odstępu QT.

Słowa kluczowe: zespół wydłużonego QT, padaczka, nagłe zatrzymanie krążenia

Folia Cardiologica 2015; 10, supl. C: 4-6

\section{Opis przypadku}

Nieprzytomnego 5-letniego chłopca po nagłym zatrzymaniu krążenia (SCA, sudden cardiac arrest) zespół Pogotowia Ratunkowego przywiózł na oddział intensywnej terapii (OIT). Na rycinie 1 przedstawiono zapis z monitora przy przyjęciu. Podczas hospitalizacji wielokrotnie zanotowano nawroty arytmii.

Według informacji uzyskanych od rodziców, chłopiec od 2. roku życia był pod opieką neurologa z powodu padaczki, incydentów prężeń z następującymi drgawkami i bezwiednym oddawaniem moczu i stolca. Epizody zawsze pojawiały się w godzinach rannych podczas snu. W leczeniu zastosowano lek przeciwdrgawkowy (Depakine ${ }^{\circledR}$, kwas walproinowy). Wywiad rodzinny był negatywny. Obecny napad się przedłużał; wystąpiły nieregularne, spłycone oddechy i zblednięcie. Rodzice rozpoczęli akcję reanimacyjną i wezwali zespół ratunkowy, który rozpoznał migotanie komór. W wyniku wykonania kilkukrotnej defibrylacji oraz podania amiodaronu przywrócono rytm zatokowy, a chłopca przewieziono na OIT.

Analiza krótkich zapisów z monitora pozwoliła na ustalenie rozpoznania - zespołu wydłużonego QT (LQTS, long
QT syndrome) (ryc. 1C). Stabilizację elektryczną uzyskano po zastosowaniu czasowej stymulacji zewnętrznej, hipotermii, oddechu wspomaganego oraz wyrównaniu zaburzeń elektrolitowych. Na rycinie 2 przedstawiono spoczynkowy zapis elektrokardiograficzny (EKG).

\section{Omówienie}

Nawracające napady drgawkowe często sugerują rozpoznanie padaczki. Negatywny wynik badania elektroencefalograficznego (EEG) nie ma znaczenia wykluczającego taką diagnozę, ale może sugerować inną przyczynę powtarzającego się stanu hipoperfuzji tkanki mózgowej, objawiającą się drgawkami lub omdleniami [1-3]. W diagnostyce różnicowej wciąż są pomijane inne, rzadsze jednostki o podobnej manifestacji, których przykładem może być wrodzony LQTS. Mimo wysokiego odsetka występowania nagłego zgonu sercowego i dostępności narzędzia diagnostycznego, jakim jest EKG, rzadkość występowania LQTS i negatywny wywiad rodzinny opóźniają właściwe rozpoznanie i wdrożenie odpowiedniego postępowania terapeutycznego.

Zarówno w Polsce, jak i na całym świecie opisuje się liczne przypadki późnego rozpoznania LQTS [4-6]. Głównym 
A

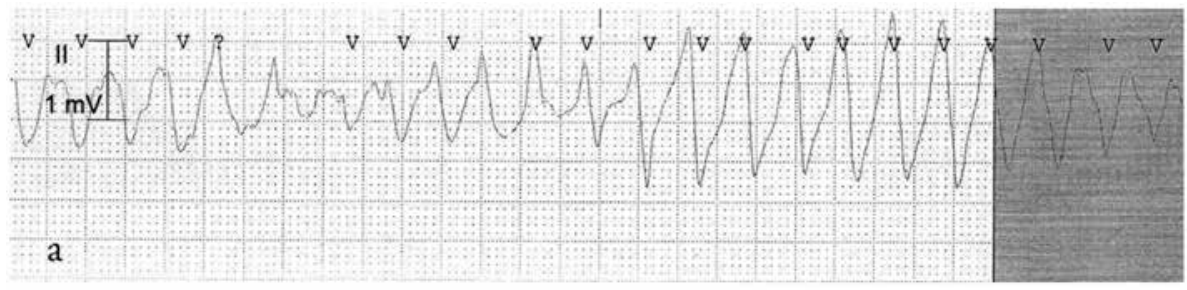

B

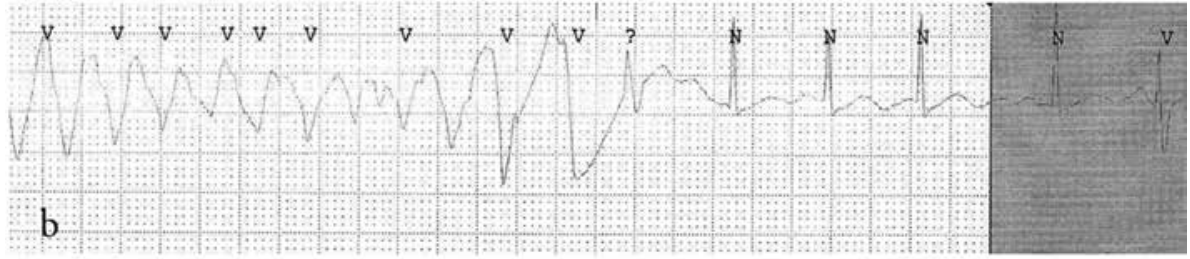

C

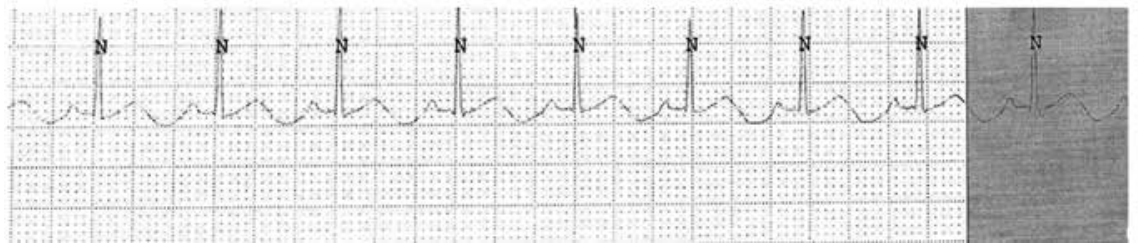

Rycina 1A-C. Zapis z kardiomonitora uzyskany na oddziale intensywnej terapii, przesuw papieru $25 \mathrm{~mm} / \mathrm{s}$, cecha $10 \mathrm{~mm} / \mathrm{mV}$ : A, B. Samoustępujący, wielokształtny częstoskurcz komorowy o morfologii torsade de pointes (TdP) i częstości 200-220/min; C. Po powrocie rytmu zatokowego 98/min odstęp QT wynosił $440 \mathrm{~ms}$, a QTc - $588 \mathrm{~ms}$

A

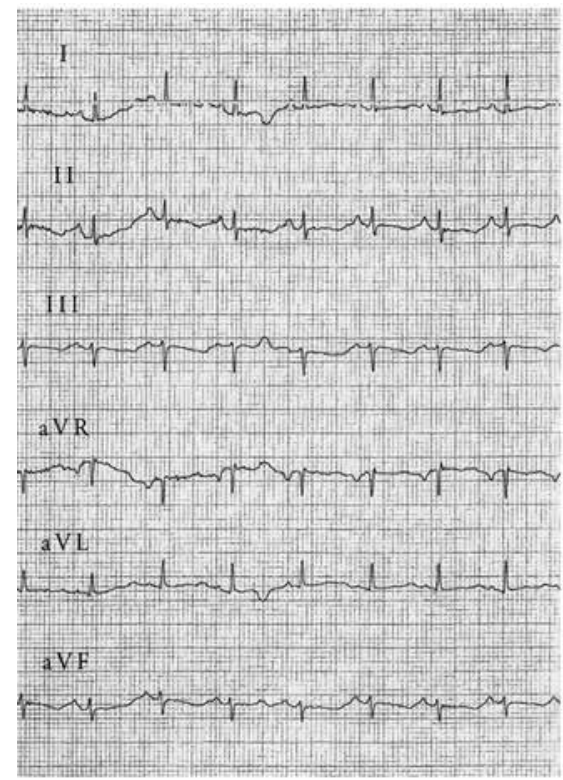

B

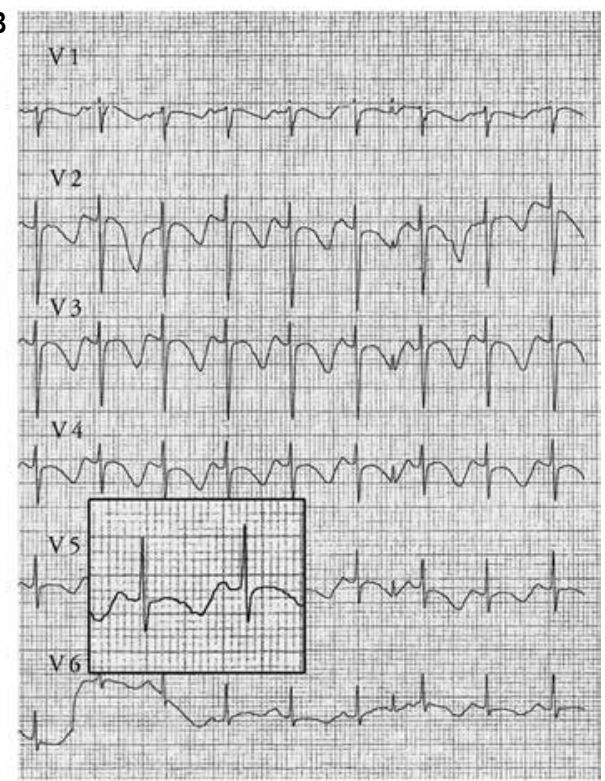

Rycina 2A, B. Zapis 12-odprowadzeniowego elektrokardiogramu, przesuw $25 \mathrm{~mm} / \mathrm{s}$, cecha $10 \mathrm{~mm} / \mathrm{mV}$ : miarowy rytm zatokowy o częstości 100/min, oś $+5^{\circ}$, odstęp PQ 160 ms, zespół QRS 80 ms, spłaszczone załamki T w odprowadzeniach kończynowych, dwufazowe załamki T w odprowadzeniach kończynowych, odstęp QT $400 \mathrm{~ms}$, QTc $548 \mathrm{~ms}$

problemem pacjentów obciążonych tą kanałopatią jest wysokie ryzyko wystąpienia nagłego zgonu sercowego $20 \%$ pacjentów umiera w przebiegu SCA w ciągu roku od wystąpienia pierwszych objawów [6].
Dwunastoodprowadzeniowe badanie EKG jest tanim, prostym i ogólnodostępnym narzędziem diagnostycznym. Ograniczeniem tej metody jest jej nieprzydatność w przypadku bezobjawowych, obciążonych mutacją pacjentów bez 


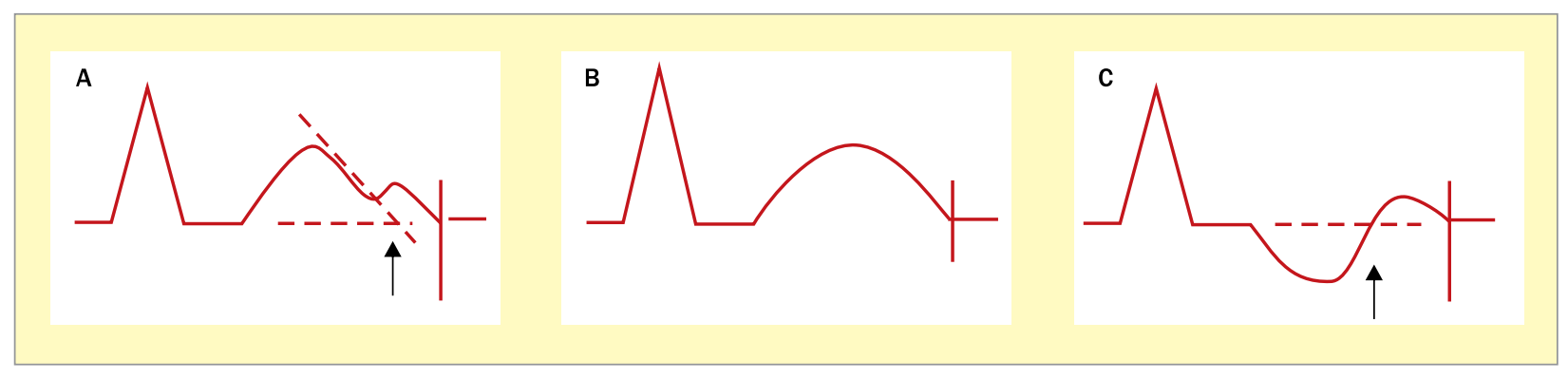

Rycina 3A-C. Diagram ilustrujący odstęp QT i trzy rodzaje zespołów TU. Strzałkami zaznaczono końce zmierzonego odstępu QT z wykluczeniem fali U. Pionowe linie wskazują koniec zmierzonego odstępu QT z włączeniem do pomiaru fali U (źródło: Lanjewar P. i wsp. Issues in QT interval measurement. Indian Pacing Electrophysiol. J. 2004; 4: 156-161)

objawów, u których mimo prawidłowej wartości QTc ryzyko SCA jest wyższe niż w zdrowej populacji [7]. Problem stanowi również umiejętność prawidłowej oceny zapisu EKG w kontekście oceny odstępu QT i oszacowania QTc (ryc. 3) [4].

Można przypuszczać, że wcześniej przeprowadzone badanie EKG w procesie diagnostycznym niewyjaśnionych i niepotwierdzonych w badaniach neurologicznych stanów drgawkowych zmniejszyłoby odsetek późnych rozpoznań LQTS, a tym samym ograniczyłoby śmiertelność $w$ przebiegu migotania komór u tych pacjentów.

\section{Konflikt interesów}

Autorzy deklarują brak konfliktu interesów.

\section{Abstract}

Long QT syndrome is a congenital disorder characterized by increased risk of sudden cardiac death, which still poses a diagnostic challenge. We present a case of 5-year-old boy diagnosed with epilepsy, who underwent sudden cardiac arrest during a seizure attack. After reanimation the patient was taken to an Intensive Care Unit, where a cardiac monitoring revealed recurent monomorfic ventricular tachycardia and torsade de pointes episodes. As the sinus rythm returned, the a prolongation of the QT intervals was described.

Key words: Iong QT syndrome, epilepsy, sudden cardiac arrest

Folia Cardiologica 2015; 10, supl. C: 4-6

\section{Piśmiennictwo}

1. Petkar S., Cooper P., Fitzpatrick A.P. How to avoid a misdiagnosis in patients presenting with transient loss of consciousness. Postgrad. Med. J. 2006; 82: 630-641.

2. Smith D., Defalla B.A., Chadwick D.W. The misdiagnosis of epilepsy and the management of refractory epilepsy in a specialist clinic. QJM 1999; 92: 15-23.

3. Zaidi A., Clough P., Cooper P. i wsp. Misdiagnosis of epilepsy: many seizure-like attacks have a cardiovascular cause. J. Am. Coll. Cardiol. 2000; 36: 181-184.
4. MacCormick J.M., McAlister H., Crawford J. i wsp. Misdiagnosis of long QT syndrome as epilepsy at first presentation. Ann. Emerg. Med. 2009; 54: 26-32.

5. Medford B.A., Bos J.M., Ackerman M.J. Epilepsy misdiagnosed as long QT syndrome: it can go both ways. Congenit. Heart Dis. 2014; 9: E135-E139.

6. Schwartz P.J. Idiopathic long QT syndrome: progress and questions. Am. Heart J. 1985; 109: 399-411.

7. Goldenberg I., Horr S., Moss A.J. i wsp. Risk for life-threatening cardiac events in patients with genotype-confirmed long-QT syndrome and normal-range corrected QT intervals. J. Am. Coll. Cardiol. 2011; 57: 51-59. 